\title{
Thyroid function is not affected 6 or 24 hours after subcutaneous low molecular weight heparin
}

\section{Brak wptywu podskórnej iniekcji heparyny drobnocząsteczkowej na funkcje tarczycy po 6 lub 24 godzinach od podania}

\author{
Abbas Ali Mansour ${ }^{1}$, Hayder Qassim Kadim² \\ ${ }^{1}$ Faiha Specialised Diabetes, Endocrine, and Metabolism Centre (FDEMC), Chair, Diabetes, Endocrine, and Metabolism Division, \\ Department of Medicine, Basrah College of Medicine, Basrah, Iraq \\ ${ }^{2}$ Basrah Health Directorate, Basrah, Iraq
}

Key words: low molecular weight heparin, enoxaparin, thyroid function, thyroid hormone.

Słowa kluczowe: heparyna drobnocząsteczkowa, enoksaparyna, funkcja tarczycy, hormon tarczycy.

\begin{abstract}
Introduction: There has been widespread use of low molecular weight heparin (LMWH) in medical and surgical practice over the years.

Aim of the research: To see the effect of LMWH on thyroid function.

Material and methods: a cross-sectional study was made of patients with acute coronary syndrome (ACS) admitted to the Faiha Hospital Coronary Care Unit (CCU) for the period from December 2014 to June 2015. We enrolled 70 patients, with no apparent clinical history or examination finding suggestive of thyroid disease. On admission for all, enoxaparin (4000-6000 units) was given subcutaneously once daily with other usual drugs used for ACS. Thyroid function test was done at baseline and after $6 \mathrm{~h}$ in 60 patients and after $24 \mathrm{~h}$ in 10 patients.

Results: At the end of the study, we excluded three patients (TSH $>10$ (1 patient) or TSH $<0.2$ ( 2 patients)). So the total number of enrolled patients was 67; 57 patients were from the 6-hour group and 10 from the 24-hour group. Comparison between serum levels of thyroid hormones (TSH, free T4, total T4, and total T3) measured at time of admission, $6 \mathrm{~h}$ later in 57 patients and $24 \mathrm{~h}$ in 10 patients, showed no statistical difference in the level after low molecular weight heparin (enoxaparin) except for lower total T4 after $6 \mathrm{~h}(9.2 \pm 1.8$ vs. $8.8 \pm 1.8 \mu \mathrm{g} / \mathrm{dl}, p=0.003)$.

Conclusions: Single-dose low molecular weight heparin (enoxaparin) given subcutaneously had no effect on thyroid hormone levels 6 or $24 \mathrm{~h}$ later in patients with ACS.
\end{abstract}

\section{Streszczenie}

Wprowadzenie: Heparyna drobnocząsteczkowa ma od lat szerokie zastosowanie w praktyce medycznej, m.in. w chirurgii. Cel pracy: Poznanie wpływu heparyny drobnocząsteczkowej na funkcję tarczycy.

Materiał i metody: Przeprowadzono przekrojowe badanie chorych z ostrymi zespołami wieńcowymi (ACS) przyjętych na oddział intensywnej opieki kardiologicznej (CCU) szpitala Faiha w okresie od grudnia 2014 r. do czerwca 2015 r. W badaniu wzięło udział 70 chorych bez wyraźnej historii klinicznej i bez wyników badań wskazujących na chorobę tarczycy. Przy przyjęciu wszystkim podawano raz dziennie enoksaparynę (4000-6000 jednostek) podskórnie wraz z innymi standardowymi lekami na ACS. Wyjściowo oraz po 6 godzinach u 60 chorych i po 24 godzinach u 10 chorych przeprowadzono badanie funkcji tarczycy.

Wyniki: Na koniec badania wyłączono 3 pacjentów (TSH > 10 (1 pacjent) lub TSH < 0,2 (2 pacjentów)). Łącznie do badania włączono 67 pacjentów, przy czym 57 pochodziło z grupy badanej po 6 godzinach, a 10 z grupy badanej po 24 godzinach. Porównanie stężeń hormonów tarczycy w surowicy (TSH, wolna T4, całkowita T4 oraz całkowita T3) zmierzonych przy przyjęciu, po upływie 6 godzin u 57 chorych oraz po upływie 24 godzin u 10 chorych nie wykazało statystycznie istotnych różnic po podaniu heparyny drobnocząsteczkowej (enoksaparyny) z wyjątkiem niższego stężenia całkowitej T4 po 6 godzinach $(9,2 \pm 1,8$ ss $8,8 \pm 1,8 \mu \mathrm{g} / \mathrm{dl}, p=0,003)$.

Wnioski: Pojedyncza dawka heparyny drobnocząsteczkowej (enoksaparyny) podana podskórnie nie miała żadnego wpływu na stężenie hormonu tarczycy po upływie 6 lub 24 godzin u chorych z ACS. 


\section{Introduction}

There has been widespread use of low molecular weight heparin (LMWH) in medical and surgical practice over the years. Heparin and thyroid dysfunction is now a new entity.

Heparin (unfractionated and LMWH) even in trace amounts used to flush the central line, can cause displacement of T4 from thyroxine-binding globulin (TBG) and causes increased free $\mathrm{T} 4$ and free $\mathrm{T} 3$, and in this case measuring total T4 could be the best alternative $[1,2]$.

The increase in free $\mathrm{T} 4$ has been just a biochemical phenomenon associated with normal thyroid-stimulating hormone (TSH) [3].

Blood samples taken $10 \mathrm{~h}$ from heparin injection may avoid the risk of alteration of free thyroid hormones induced by heparin [4], and some advocate the measurement of total T4 during heparin treatment [5].

One study found a five-fold increase of free T4 within 2-15 min when heparin was given intravenously to 9 healthy subjects and 5 with hypothyroidism. Furthermore, adding heparin to the blood sample in vitro had no effect on free $\mathrm{T} 4$, indicating that this change is due to an in vivo effect [6].

Heparin's effect on free thyroid hormone levels was seen with equilibrium dialysis, ultracentrifugation, and direct immunoassay methods of assay [3].

The mechanisms of heparin-induced increase in free T4 includes heparin increased non-esterified fatty acids (NEFA) because heparin stimulates lipase activity, which happens in vivo and to a greater extent in vitro in the tube of the blood that causes increased free $\mathrm{T} 4$ by displacing it from the TBG. This increase in free $\mathrm{T} 4$ increased if there was associated hypertriglyceridaemia, low albumin, or prolonged incubation of the blood sample at $37^{\circ} \mathrm{C}$ [2].

This effect of heparin on free $\mathrm{T} 4$ is transient and acute, and is probably an in vitro phenomena due to the generation of free fatty acids by heparin stimulation of lipoprotein lipase, and requires serum triglyceride more than $180 \mathrm{mg} / \mathrm{dl}(2 \mathrm{mmol} / \mathrm{l})$ [7].

However, in renal failure on dialysis with heparin use, free T4 measurement may reflect non-thyroidal illness [8].

Intravenous heparin blunts the response of TSH to TRH within $24 \mathrm{~h}$, which suggests that the rise in serum free thyroid hormones, which heparin produces, has a metabolic effect [9].

In thyroid storm, resistance to the heparin effect was expected with a positive correlation between factor VIII and thyroxin levels and higher doses of heparin needed [10].

An in vitro tube containing heparin lithium does not affect serum levels of TSH, free T4 by chemiluminescence assay [11].

Most, if not all the studies on the effect of heparin on free T4 were old, dated back to three decades ago [12-14].

\section{Aim of the research}

The aim of the study was to see the effect of low molecular weight heparin on thyroid function in persons admitted to the CCU for acute coronary syndrome with apparently no previous thyroid disease. This effect, if proven, will affect the interpretation of thyroid function in patients on heparin.

\section{Material and methods \\ Design}

A cross-sectional study of patients with acute coronary syndrome (ACS) admitted to the Faiha Hospital coronary care unit (CCU).

\section{Study participants}

For the period from December 2014 to June 2015 we enrolled 70 patients with no apparent clinical history or local examination of the neck finding suggestive of thyroid disease.

The local health system in Basrah Hospital sees patients with ACS in the emergency room, and after baseline ECG and biomarkers the patients are moved to the $\mathrm{CCU}$ in the hospital within $6 \mathrm{~h}$ (usually 30-60 min). On admission, for everyone unless they have contraindications, enoxaparin (4000-6000 units) is given subcutaneously once daily with other usual drugs used for ACS (aspirin, clopidogrel, angiotensin converting enzyme inhibitors, $\beta$-blockers, and morphine).

Verbal informed consent was taken from all patients.

\section{Exclusion criteria}

Pregnant women, cases of hypothyroidism, hyperthyroidism, thyroiditis, on amiodarone in the last 3 months, family history of either hypothyroidism or hyperthyroidism, hospitalisation or radiocontrast study in the past 1 months, and those who stayed more than $6 \mathrm{~h}$ in the emergency units.

\section{Study procedures}

On admission before the enoxaparin and within 1-30 min of admission, $5 \mathrm{ml}$ of blood was taken from the patients then centrifuged immediately and kept frozen at $-20^{\circ} \mathrm{C}$ for subsequent thyroid hormone assay. The second sample was taken $6 \mathrm{~h}$ later from 60 patients after enoxaparin doses had been given. A further 10 patients had blood samples taken at admission and $24 \mathrm{~h}$ later without the 6-hour sampling.

\section{Definition of variables}

Hypertension and diabetes were defined as previous diagnosis by doctors and on treatment. Body mass index (BMI) was calculated as weight in kilograms divided by the square of height in metres. A current cig- 


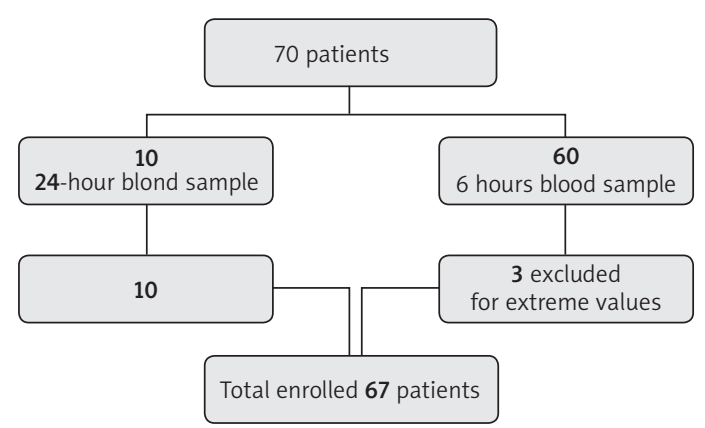

Figure 1. Study sample

Table 1. Baseline characteristics (mean \pm SD or number (\%))

\begin{tabular}{|c|c|c|}
\hline \multicolumn{2}{|l|}{ Parameter } & Result \\
\hline \multicolumn{2}{|l|}{ Age [years] } & $61.4 \pm 13.2$ \\
\hline \multirow[t]{2}{*}{ Age group [years] } & $>50$ & $46(68.7)$ \\
\hline & $\leq 50$ & $21(31.3)$ \\
\hline \multirow[t]{2}{*}{ Gender } & Men & $40(59.7)$ \\
\hline & Women & $27(40.3)$ \\
\hline \multicolumn{2}{|l|}{ BMI $\left[\mathrm{kg} / \mathrm{m}^{2}\right]$} & $27.6 \pm 3.4$ \\
\hline \multicolumn{2}{|c|}{ Systolic blood pressure [mm Hg] } & $141.3 \pm 22.2$ \\
\hline \multicolumn{2}{|c|}{ Diastolic blood pressure [mm Hg] } & $85.4 \pm 12.9$ \\
\hline \multicolumn{2}{|l|}{ Hypertension } & $35(52.2)$ \\
\hline \multicolumn{2}{|l|}{ Diabetes } & $28(41.8)$ \\
\hline \multicolumn{2}{|l|}{ Current smokers } & $19(28.4)$ \\
\hline \multirow[t]{2}{*}{ Sample time } & 0 and $6 \mathrm{~h}$ & $57(85.1)$ \\
\hline & 0 and $24 \mathrm{~h}$ & $10(14.9)$ \\
\hline \multicolumn{2}{|l|}{ Total } & $67(100)$ \\
\hline
\end{tabular}

arette smoker was defined as a person smoking daily or on some days during the past 30 days.

\section{Laboratory analysis}

For all the enrolled patients, the serum was analysed on the next working day (working days in Iraq are from 8 a.m.-2 p.m.) for thyroid function as follows: The following thyroid tests were carried out for all, including TSH, free T4, total T3, and total T4, and thyroid peroxidase antibodies (anti-TPO) using Cobas e411 immunoassay analysers - Roche, Germany using electrochemiluminescence (ECL) technology. The thyroid peroxidase antibodies (anti-TPO) was measured only once at time zero. Normal values were as follows: for TSH, 0.27-4.2 $\mu \mathrm{IU} / \mathrm{ml}$; free T4, 0.93-1.7 ng/ dl; total T4, 5.1-14.1 $\mu \mathrm{g} / \mathrm{dl}$; total T3, 0.8-2.0 ng/ml; and anti-TPO, 0-34 IU/ml.
Table 2. Thyroid hormone levels at basal and $6 \mathrm{~h}$ (mean \pm SD or number (\%))

\begin{tabular}{|lccc|}
\hline Thyroid hormones & 0 time & $6 \mathrm{~h}$ & $P$-values \\
TSH $[\mu \mathrm{lU} / \mathrm{ml}]$ & $1.8 \pm 1.3$ & $1.7 \pm 1.5$ & 0.526 \\
Free T4 $[\mathrm{ng} / \mathrm{dl}]$ & $1.3 \pm 0.2$ & $1.3 \pm 0.2$ & 0.191 \\
Total T4 $[\mu \mathrm{g} / \mathrm{dl}]$ & $9.2 \pm 1.8$ & $8.8 \pm 1.8$ & 0.003 \\
Total T3 $[\mathrm{ng} / \mathrm{ml}]$ & $1.2 \pm 0.3$ & $0.2 \pm 0.4$ & 0.628 \\
$\begin{array}{l}\text { Thyroid antibodies: } \\
\begin{array}{l}\text { Anti-TPO antibodies } \\
\text { positive }\end{array}\end{array}$ & & $19(29.2)$ & \\
\hline
\end{tabular}

${ }^{*}$ Of those examined (65 patients) 2 (3\%) had missing values.

Table 3. Thyroid hormone levels at basal and $24 \mathrm{~h}$ $($ mean \pm SD)

\begin{tabular}{|lccc|}
\hline Thyroid hormones & 0 time & $24 \mathrm{~h}$ & $P$-values \\
TSH $[\mu \mathrm{lU} / \mathrm{ml}]$ & $1.4 \pm 0.4$ & $1.1 \pm 0.3$ & 0.053 \\
Free T4 $[\mathrm{ng} / \mathrm{dl}]$ & $1.4 \pm 0.3$ & $1.3 \pm 0.3$ & 0.575 \\
Total T4 $[\mu \mathrm{g} / \mathrm{dl}]$ & $10.4 \pm 3.2$ & $8.3 \pm 1.4$ & 0.059 \\
Total T3 $[\mathrm{ng} / \mathrm{ml}]$ & $1.1 \pm 0.2$ & $1.0 \pm 0.2$ & 0.182 \\
\hline
\end{tabular}

\section{Statistical analysis}

All data were entered in SPSS version 15 for analysis. Continuous variables were summarised as the mean and standard deviation. Categorical variables were summed up as a percentage. A Student $t$-test was used to determine if there was a significant difference between the mean using paired sample $t$-test. Analysis of variance (ANOVA) was used to analyse the differences among group means.

\section{Results}

At the end of the study, we excluded three patients (TSH $>10$ (1 patient) or TSH < 0.2 ( 2 patients)). So, the total number of enrolled patients was 67: 57 patients were from the 6-hour group and 10 from the 24-hour group (Figure 1).

Men constituted 59.7\%, and $68.7 \%$ were aged more than 50 years in this study (Table 1). The mean BMI was $27.6 \pm 3.4 \mathrm{~kg} / \mathrm{m}^{2}, 52.2 \%$ were hypertensive, and $41.8 \%$ were with type 2 diabetes mellitus. $28.4 \%$ were current smokers.

Comparison between serum levels of thyroid hormones (TSH, free T4, total T4, and total T3) measured at time of admission, $6 \mathrm{~h}$ later in 57 patients, and $24 \mathrm{~h}$ in 10 patients showed no statistical difference in the level after low molecular heparin (enoxaparin), as seen in Table 2, except for lower total T4 after $6 \mathrm{~h}(9.2$ \pm 1.8 vs. $8.8 \pm 1.8 \mu \mathrm{g} / \mathrm{dl}$ ) with $p$-values $=0.003$. Total $\mathrm{T} 4$ decreased $6 \mathrm{~h}$ after heparin significantly, but the decline at $24 \mathrm{~h}$ was not statistically significant (Table 3). The prevalence of anti-TPO antibodies was $29.2 \%$ in this cohort. 
Table 4. Thyroid hormone levels, according to different confounders after $6 \mathrm{~h}$ or $24 \mathrm{~h}$

\begin{tabular}{|c|c|c|c|c|c|c|}
\hline Parameter & & $\begin{array}{c}\mathrm{TSH}, \text { mean } \pm \text { SD } \\
{[\mu \mathrm{lU} / \mathrm{ml}]}\end{array}$ & $\begin{array}{c}\text { Free T4, mean } \pm \text { SD } \\
{[\mathrm{ng} / \mathrm{dl}]}\end{array}$ & $\begin{array}{l}\text { Total T4, mean } \\
\pm \mathrm{SD}[\mu \mathrm{g} / \mathrm{dl}]\end{array}$ & $\begin{array}{c}\text { Total T3 mean } \pm \\
\text { SD }[\mathrm{ng} / \mathrm{ml}]\end{array}$ & $P$-values* \\
\hline \multirow[t]{2}{*}{ Age [years] } & $<50$ & $1.4 \pm 1.1$ & $1.3 \pm 0.3$ & $9.1 \pm 1.5$ & $1.3 \pm 0.3$ & \multirow[t]{2}{*}{0.344} \\
\hline & $\geq 50$ & $1.7 \pm 1.5$ & $1.3 \pm 0.2$ & $8.6 \pm 1.8$ & $1.1 \pm 0.4$ & \\
\hline \multirow[t]{2}{*}{ Gender } & Men & $1.3 \pm 1.1$ & $1.3 \pm 0.2$ & $8.3 \pm 1.9$ & $1.1 \pm 0.3$ & \multirow[t]{2}{*}{0.007} \\
\hline & Women & $2.2 \pm 1.6$ & $1.4 \pm 0.2$ & $9.4 \pm 1.2$ & $1.3 \pm 0.5$ & \\
\hline \multirow[t]{2}{*}{ Hypertensive } & Yes & $1.9 \pm 1.6$ & $1.3 \pm 0.2$ & $8.4 \pm 1.7$ & $1.1 \pm 0.4$ & \multirow[t]{2}{*}{0.252} \\
\hline & No & $1.4 \pm 1.1$ & $1.4 \pm 0.3$ & $9.1 \pm 1.6$ & $1.3 \pm 1.3$ & \\
\hline \multirow[t]{2}{*}{ Diabetes } & Yes & $1.9 \pm 1.5$ & $1.3 \pm 0.3$ & $8.7 \pm 1.8$ & $1.2 \pm 0.5$ & \multirow[t]{2}{*}{0.424} \\
\hline & No & $1.4 \pm 1.3$ & $1.3 \pm 0.2$ & $8.8 \pm 1.6$ & $1.2 \pm 0.3$ & \\
\hline \multirow{2}{*}{$\begin{array}{l}\text { Current } \\
\text { smoker }\end{array}$} & Yes & $1.3 \pm 0.9$ & $1.3 \pm 0.2$ & $8.6 \pm 1.6$ & $1.1 \pm 0.3$ & \multirow[t]{2}{*}{0.129} \\
\hline & No & $1.7 \pm 1.5$ & $1.3 \pm 0.3$ & $8.9 \pm 1.7$ & $1.2 \pm 0.4$ & \\
\hline \multirow{2}{*}{$\begin{array}{l}\text { Anti-TPO } \\
\text { positive }\end{array}$} & Yes & $1.9 \pm 1.6$ & $1.4 \pm 0.3$ & $8.7 \pm 1.6$ & $1.2 \pm 0.4$ & \multirow[t]{2}{*}{0.177} \\
\hline & No & $1.5 \pm 1.3$ & $1.3 \pm 0.2$ & $8.7 \pm 1.8$ & $1.2 \pm 0.4$ & \\
\hline
\end{tabular}

${ }^{*}$ Based on ANOVA between the mean of thyroid function.

There was no difference in the thyroid hormone level when age, hypertension state, diabetes, current smoking, or thyroid antibody positivity were used as the co-founders to see if they affected the level of thyroid hormones 6 or $24 \mathrm{~h}$ after low molecular weight heparin (enoxaparin) injection (Table 4), except where it was higher among women $(p$-value $=0.007)$.

\section{Discussion}

This study clearly demonstrated that low molecular weight heparin (enoxaparin) given subcutaneously to patients with ACS has no effect on thyroid hormone levels if they are measured 6 or $24 \mathrm{~h}$ after injection, except for one unexplained finding of lower total T4 $6 \mathrm{~h}$ after heparin. None of the co-founders used in this study affected the thyroid hormone level.

By any means, heparin-induced thyroid hormone changes are always transient [15]. The recommendation to avoid measuring thyroid hormones in patients on fractionated or unfractionated heparin [16] seems to be based on no real evidence, as we have seen in this study that measurement 6 to $24 \mathrm{~h}$ after heparin there was no effect on free $\mathrm{T} 4$ or other thyroid hormones.

The plethora of literature on thyroid hormones and heparin was mainly based on case reports and weird thyroid function test explanations in the reviews [2, 17].

Because the half-life of low molecular heparin (enoxaparin) is prolonged, the waning effect on thyroid function after $6-24 \mathrm{~h}$ is unlikely to be the explanation of our data $[13,17]$.

Could the subcutaneous route cause fewer changes in the thyroid hormone level because it generates less lipase, and could these changes be due only to intravenous heparin? These questions remain to be answered [13].

However, in a study of nine healthy volunteers, subcutaneous heparin (enoxaparin, 2000 units) increased measured FT4 by up to $63 \%$, and repeating the dose with enoxaparin, 2000 units twice a day, the measurement of free T4 about 2-6 h after injection increased by up to $171 \%$ [3].

Our study consolidated the idea, suggested by some authors, that heparin-induced increase in free T4 is usually an in vitro artefact, and that most subjects receiving heparin have a normal plasma free $\mathrm{T} 4$ concentration in vivo [13].

One of the explanations for the negative results of our study, besides the timing, is the normal albumin and triglycerides that are mandatory co-founders to produce alteration in thyroid function after heparin [3].

Our research finding is unlikely to be explained by non-thyroidal illness syndrome [18] because the total T3 remained unchanged and the sole reduction of total T4 is not a strong enough criterion.

Anti-TPO was positive among $29.2 \%$ of this study cohort. We have no explanation for this high level of autoantibodies in this group of patients, which is three times greater than that seen in the USA, where in the National Health and Nutrition Examination Survey (NHANES) III study anti-TPO was positive in $11.3 \%$ of thyroid disease-free subjects [19].

Properly measuring thyroid hormones level within 15-20 min of heparin could have an effect, but this was not done in this study. Also, albumin and triglyceride should have been measured at the same time. 


\section{Conclusions}

Single dose low molecular weight heparin (enoxaparin) given subcutaneously had no effect on thyroid hormone levels 6 or $24 \mathrm{~h}$ later in patients with ACS.

\section{Conflict of interest}

The authors declare no conflict of interest.

\section{References}

1. Stockigt JR. Free thyroid hormone measurement. A critical appraisal. Endocrinol Metab Clin North Am 2001; 30: 265-289.

2. Jaume JC, Mendel CM, Frost PH, Greenspan FS, Laughton CW. Extremely low doses of heparin release lipase activity into the plasma and can thereby cause artifactual elevations in the serum-free thyroxine concentration as measured by equilibrium dialysis. Thyroid 1996; 6: 79-83.

3. Koulouri O, Gurnell M. How to interpret thyroid function tests. Clin Med 2013; 13: 282-286.

4. Stevenson HP, Archbold GP, Johnston P, Young IS, Sheridan $\mathrm{B}$. Misleading serum free thyroxine results during low molecular weight heparin treatment. Clin Chem 1998; 44: 1002-1007.

5. Stockigt JR, Lim CF. Medications that distort in vitro tests of thyroid function, with particular reference to estimates of serum free thyroxine. Best Pract Res Clin Endocrinol Metab 2009; 23: 753-767.

6. Schatz DL, Sheppard RH, Steiner G, Chandarlapaty CS, de Veber GA. Influence of heparin on serum free thyroxine. J Clin Endocrinol Metab 1969; 29: 1015-1022.

7. Drug interactions with thyroid hormones - Up To Date. Available at: http://www.uptodate.com/contents/drug-interactions-with-thyroid-hormones. Accessed at October, $2^{\text {nd }}, 2014$.

8. Okabayashi T, Takeda K, Kawada M, Kubo Y, Nakamura S, Chikamori K, Terao N, Hashimoto K. Free thyroxine concentrations in serum measured by equilibrium dialysis in chronic renal failure. Clin Chem 1996; 42: 1616-1620.

9. Thomson JE, Baird SG, Beastall GH, Ratcliffe WA, Thomson JA. The effect of intravenous heparin infusions on the thyroid stimulating hormone response to thyrotropin releasing hormone. Br J Clin Pharmacol 1978; 6: 239-242.

10. Belchikov YG, Marotta SE. Heparin management in a patient with thyroid storm. Pharmacotherapy 2010; 30: 134e-138e.

11. He GR, Cheng W, Huang YY. Effect of heparin lithium as an anticoagulant in the assay of FT3, FT4, and TSH. Di Yi Jun Yi Da Xue XueBao 2002; 22: 721-723.

12. 12.Wilkins TA, Midgley JE, Giles AF. Treatment with heparin and results for free thyroxin: an in vivo or an in vitro effect? Clin Chem 1982; 28: 2441-2443.

13. Mendel CM, Frost PH, Kunitake ST, Cavalieri RR. Mechanism of the heparin-induced increase in the concentration of free thyroxine in plasma. J Clin Endocrinol Metab 1987; 65: 1259-1264.

14. Herschman JM, Jones CM, Bailey AL. Reciprocal changes in serum thyrotropin and free thyroxine produced by heparin. J Clin Endocrinol Metab 1972; 34: 574-579.

15. Surks MI, Sievert R. Drugs and thyroid function. N Engl J Med 1995; 333: 1688-1694.
16. Koulouri O, Moran C, Halsall D, Chatterjee K, Gurnell M. Pitfalls in the measurement and interpretation of thyroid function tests. Best Pract Res Clin Endocrinol Metab 2013; 27: 745762.

17. Laji K, Rhidha B, John R, Lazarus J, Davies JS. Abnormal serum free thyroid hormone levels due to heparin administration. QJM 2001; 94: 471-473.

18. Van den Berghe G. Non-thyroidal illness in the ICU: a syndrome with different faces. Thyroid 2014; 24: 14561465.

19. Spencer CA, Hollowell JG, Kazarosyan M, Braverman LE. National Health and Nutrition Examination Survey III thyroid-stimulating hormone (TSH)-thyroperoxidase antibody relationships demonstrate that TSH upper reference limits may be skewed by occult thyroid dysfunction. J Clin Endocrinol Metab 2007; 92: 4236-4240.

\section{Address for correspondence:}

Prof. Abbas Ali Mansour MD, FRCP, FACE

Faiha Specialised Diabetes, Endocrine, and Metabolism Centre Chair, Diabetes, Endocrine, and Metabolism Division

Department of Medicine

Basrah College of Medicine

P.O Box 142, Basrah, Iraq

Phone: 009647801403706

E-mail: aambaam@gmail.com 